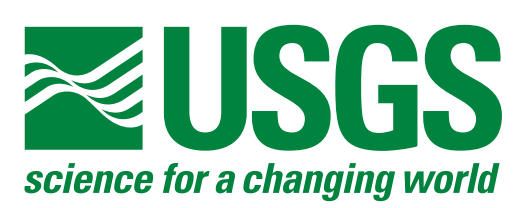

Seasonal Flux and Assemblage Composition of Planktic Foraminifera from the Northern Gulf of Mexico, 2008-2012

By Caitlin E. Reynolds, Julie N. Richey, and Richard Z. Poore

Open-File Report 2013-1243

U.S. Department of the Interior

U.S. Geological Survey 


\section{U.S. Department of the Interior \\ SALLY JEWELL, Secretary}

\section{U.S. Geological Survey \\ Suzette M. Kimball, Acting Director}

U.S. Geological Survey, Reston, Virginia: 2013

For more information on the USGS-the Federal source for science about the Earth, its natural and living resources, natural hazards, and the environment-visit http://www. usgs.gov or call 1-888-ASK-USGS

For an overview of USGS information products, including maps, imagery, and publications, visit http://www.usgs.gov/pubprod

To order this and other USGS information products, visit http://store.usgs.gov

Suggested citation:

Reynolds, C.E., Richey, J.N., and Poore, R.Z., 2013, Seasonal flux and assemblage composition of planktic foraminifera from the northern Gulf of Mexico, 2008-2012: U.S. Geological Survey Open-File Report 2013-1243, 13 p.

Any use of trade, product, or firm names is for descriptive purposes only and does not imply endorsement by the U.S. Government.

Although this report is in the public domain, permission must be secured from the individual copyright owners to reproduce any copyrighted material contained within this report. 


\section{Contents}

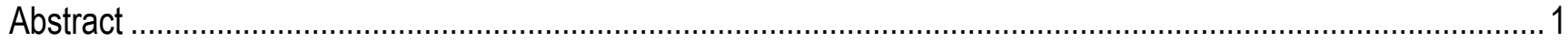

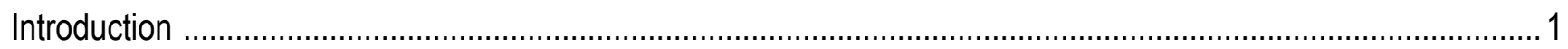

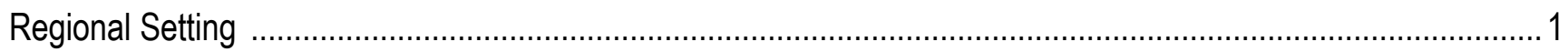

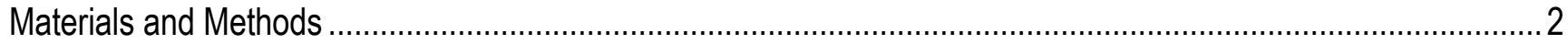

Results from 2012

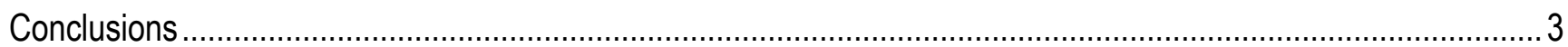

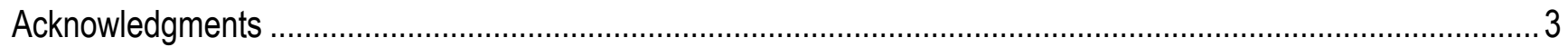

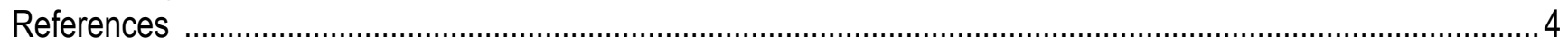

\section{Figures}

1. Location of the sediment-trap mooring (inverted triangle) in the northern Gulf of Mexico at approximately $25.7^{\circ} \mathrm{N}$ latitude and $90.3^{\circ} \mathrm{W}$ longitude.

2. Temperature depth profiles of World Ocean Atlas 2009 climatology (monthly average) (WOA09) and conductivity-temperature-depth (CTD) casts for the sediment trap during 2008-2012.

3. Salinity depth profiles of World Ocean Atlas 2009 climatology (monthly average) (WOA09) and conductivitytemperature-depth (CTD) casts for the sediment trap during 2008-2012.

4A. Average daily flux of 7- to 14-day-long sampling intervals of all planktic foraminifers and the 10 most abundant species/groups during 2008-2012. Note the scale change in the y-axis. The tick marks on the $x$-axis denote the first day of each month. There was a gap in sampling from late May to late September 2009 and early February to late March 2012 (red rectangles) and loss of nine sample cups (red inverted triangles). $\mathrm{m}^{-2}$ day ${ }^{-1}$, square meter per day.

4B. Average daily flux of 7- to 14-day-long sampling intervals of all planktic foraminifers and the 10 most abundant species/groups during 2008-2012. Note the scale change in the y-axis. The tick marks on the $x$-axis denote the first day of each month. There was a gap in sampling from late May to late September 2009 and early February to late March 2012 (red rectangles) and loss of nine sample cups (red inverted triangles). $\mathrm{m}^{-2}$ day $^{-1}$, square meter per day.

4C. Average daily flux of 7- to 14-day-long sampling intervals of all planktic foraminifers and the 10 most abundant species/groups during 2008-2012. Note the scale change in the y-axis. The tick marks on the $x$-axis denote the first day of each month. There was a gap in sampling from late May to late September 2009 and early February to late March 2012 (red rectangles) and loss of nine sample cups (red inverted triangles). $\mathrm{m}^{-2}$ day $^{-1}$, square meter per day.

4D. Average daily flux of 7- to 14-day-long sampling intervals of all planktic foraminifers and the 10 most abundant species/groups during 2008-2012. Note the scale change in the y-axis. The tick marks on the $x$-axis denote the first day of each month. There was a gap in sampling from late May to late September 2009 and early February to late March 2012 (red rectangles) and loss of nine sample cups (red inverted triangles). $\mathrm{m}^{-2}$ day $^{-1}$, square meter per day. 
5A. Weekly percent abundance of the 10 most common species/groups of planktic foraminifers during 20082012. Note the scale change in the $y$-axis. The tick marks on the $x$-axis denote the first day of each month. There was a gap in sampling from late May to late September 2009 and early February to late March 2012

(red rectangles) and loss of nine sample cups (red inverted triangles).

5B. Weekly percent abundance of the 10 most common species/groups of planktic foraminifers during 20082012. Note the scale change in the $y$-axis. The tick marks on the $x$-axis denote the first day of each month. There was a gap in sampling from late May to late September 2009 and early February to late March 2012 (red rectangles) and loss of nine sample cups (red inverted triangles).

\section{Tables}

1. (Please see separate file OFR-2013-1243_table.xls) Planktic foraminiferal flux (tests per square meter per day, $\mathrm{m}^{-2} \mathrm{~d}^{-1}$ ) and percent contribution (in parentheses) to the total assemblage for the 14 most common species, northern Gulf of Mexico. Table is separated by season (winter, spring, summer, and fall) and year. The first 10 species listed accounted for about 90 percent of the total flux. Particularly low fluxes ( $<50$ tests $\mathrm{m}^{-2} \mathrm{~d}^{-1}$ ) are denoted with an asterisk next to the mid-week collection date. 


\section{Conversion Factors}

\begin{tabular}{|c|c|c|}
\hline Multiply & By & To obtain \\
\hline \multicolumn{3}{|c|}{ Length } \\
\hline centimeter $(\mathrm{cm})$ & 0.394 & inch (in.) \\
\hline millimeter (mm) & 0.039 & inch (in.) \\
\hline meter $(\mathrm{m})$ & 3.281 & foot $(\mathrm{ft})$ \\
\hline kilometer (km) & 0.621 & mile (mi) \\
\hline meter $(\mathrm{m})$ & 1.094 & yard (yd) \\
\hline \multicolumn{3}{|c|}{ Area } \\
\hline square centimeter $\left(\mathrm{cm}^{2}\right)$ & 0.001 & square foot $\left(\mathrm{ft}^{2}\right)$ \\
\hline square meter $\left(\mathrm{m}^{2}\right)$ & 10.76 & square foot $\left(\mathrm{ft}^{2}\right)$ \\
\hline square centimeter $\left(\mathrm{cm}^{2}\right)$ & 0.155 & square inch $\left(\mathrm{ft}^{2}\right)$ \\
\hline \multicolumn{3}{|c|}{ Volume } \\
\hline liter (L) & 33.82 & ounce, fluid (fl. oz) \\
\hline liter (L) & 2.113 & $\operatorname{pint}(\mathrm{pt})$ \\
\hline liter (L) & 1.057 & quart (qt) \\
\hline liter (L) & 0.264 & gallon (gal) \\
\hline cubic meter $\left(\mathrm{m}^{3}\right)$ & 264.2 & gallon (gal) \\
\hline cubic meter $\left(\mathrm{m}^{3}\right)$ & 35.31 & cubic foot $\left(\mathrm{ft}^{3}\right)$ \\
\hline cubic meter $\left(\mathrm{m}^{3}\right)$ & 1.308 & cubic yard $\left(\mathrm{yd}^{3}\right)$ \\
\hline \multicolumn{3}{|c|}{ Mass } \\
\hline $\operatorname{gram}(\mathrm{g})$ & 0.035 & ounce, avoirdupois (oz) \\
\hline kilogram (kg) & 2.205 & pound avoirdupois (lb) \\
\hline \multicolumn{3}{|c|}{ Pressure } \\
\hline kilopascal (kPa) & 0.010 & atmosphere, standard (atm) \\
\hline \multicolumn{3}{|c|}{ Energy } \\
\hline joule (J) & 0.000 & kilowatthour (kWh) \\
\hline \multicolumn{3}{|c|}{ Radioactivity } \\
\hline becquerel per liter $(\mathrm{Bq} / \mathrm{L})$ & 27.027 & picocurie per liter $(\mathrm{pCi} / \mathrm{L})$ \\
\hline
\end{tabular}

Temperature in degrees Celsius $\left({ }^{\circ} \mathrm{C}\right)$ may be converted to degrees Fahrenheit $\left({ }^{\circ} \mathrm{F}\right)$ as follows: ${ }^{\circ} \mathrm{F}=\left(1.8 \times^{\circ} \mathrm{C}\right)+32$

Temperature in degrees Fahrenheit $\left({ }^{\circ} \mathrm{F}\right)$ may be converted to degrees Celsius $\left({ }^{\circ} \mathrm{C}\right)$ as follows: ${ }^{\circ} \mathrm{C}=\left({ }^{\circ} \mathrm{F}-32\right) / 1.8$ 


\title{
Seasonal Flux and Assemblage Composition of Planktic Foraminifera from the Northern Gulf of Mexico, 2008-2012
}

\author{
By Caitlin E. Reynolds, Julie N. Richey, and Richard Z. Poore
}

\begin{abstract}
The U.S. Geological Survey anchored a sediment trap in the northern Gulf of Mexico beginning in 2008 to collect seasonal time-series data on the flux and assemblage composition of live planktic foraminifers. This report provides an update of the previous time-series data to include results from 2012. Ten species, or varieties, constituted $\sim 92$ percent of the 2012 assemblage: Globigerinoides ruber (pink and white varieties), Globigerinoides sacculifer, Globigerina calida, Globigerinella aequilateralis, Globorotalia menardii group [The Gt. menardii group includes Gt. menardii, Gt. tumida, and Gt. ungulata], Orbulina universa, Globorotalia truncatulinoides, Pulleniatina spp., and Neogloboquadrina dutertrei. The mean daily flux was 158 tests per square meter per day $\left(\mathrm{m}^{-2} \mathrm{day}^{-1}\right)$, with maximum fluxes of $>450$ tests $\mathrm{m}^{-2}$ day $^{-1}$ during the beginning of July and mid-August and minimum fluxes of $<10$ tests $\mathrm{m}^{-2} \mathrm{day}^{-1}$ during the beginning of February and mid-July. Globorotalia truncatulinoides showed a clear preference for the winter, consistent with data from 2008 to 2011. Globigerinoides ruber (white) flux data for 2012 (average 23 tests $\mathrm{m}^{-2}$ day $^{-1}$ ) were consistent with data from 2011 (average 30 tests $\mathrm{m}^{-2} \mathrm{day}^{-1}$ ) and 2010 (average 29 tests $\mathrm{m}^{-2} \mathrm{day}^{-1}$ ) and showed a steady threefold increase since 2009 (average 11 tests $\mathrm{m}^{-2}$ day $\left.^{-1}\right)$ and a tenfold increase from the 2008 flux $\left(3\right.$ tests $\mathrm{m}^{-2}$ day $\left.^{-1}\right)$.
\end{abstract}

\section{Introduction}

A sediment trap was anchored in the northern Gulf of Mexico in January 2008 as part of a U.S. Geological Survey Mendenhall Postdoctoral Fellowship project. The sediment trap, equipped with an automated sampling system, has continuously collected material in the water column from January 2008 to the present. Information on the trap, trap mooring, planktic foraminifers as climate proxies, and the results from the first year are detailed in Tedesco and others (2009). In this report, we update results from the sediment-trap series to include material collected between January and December of 2012. This report presents the data without interpretation. For discussion and interpretation of flux data from 2008 to 2010, see Poore and others (2013).

\section{Regional Setting}

The Gulf of Mexico is a semi-enclosed basin surrounded by the Gulf Coast of the United States, Mexico, and Cuba (fig. 1). Sea-surface temperature (SST) at the trap site ranges from a winter low of approximately 21 degrees Celsius $\left({ }^{\circ} \mathrm{C}\right.$ ) to a high of $30^{\circ} \mathrm{C}$ (World Ocean Atlas 2009 data cited in Locarnini and others, 2010). Sea-surface salinity (SSS) ranges from about 35 practical salinity units (psu) in the winter to $32 \mathrm{psu}$ in the summer (World Ocean Atlas 2009 data cited in Antonov and others, 2010).

The Gulf of Mexico is connected to the Caribbean and tropical North Atlantic by the Loop Current. The Loop Current is a surface current that enters the Gulf of Mexico between Cuba and the Yucatan Peninsula and typically loops east and south before exiting through the Florida Straits. 
The Gulf of Mexico, Caribbean Sea, and western tropical North Atlantic compose the Atlantic Warm Pool, the Atlantic portion of the Western Hemisphere Warm Pool (Wang and Enfield, 2001). The Atlantic Warm Pool is defined by the region where the mixed layer of water is warmer than $28.5^{\circ} \mathrm{C}$ and constitutes a large part of the tropical heat engine, supplying moisture to the atmosphere and latent heat to North America from early spring to early fall (Wang and Enfield, 2001; Wang and others, 2006). World Ocean Atlas 2009 climatology indicates the trap site is part of the Atlantic Warm Pool during July, August, and September (summer) (Locarnini and others, 2010).

\section{Materials and Methods}

A McLane PARFLUX Mark 78 automated sediment trap was deployed in early January 2008 in approximately 1,150 meters $(\mathrm{m})$ of water depth at approximately $27.5^{\circ} \mathrm{N}$ latitude and $90.3^{\circ} \mathrm{W}$ longitude. The trap is positioned at a depth of $700 \mathrm{~m}$ on a mooring cable to guarantee the collection of deeper-dwelling species of planktic foraminifers (for example, Globorotalia spp.). The trap is equipped with 21 collection cups that are mounted on a rotating plate that is programmed to rotate every 7 or 14 days (representing a 1-or 2-week collection period). Sample cups from January 2008 to late May 2009 contained a buffered formalin solution made with filtered (0.44-micrometer $[\mu \mathrm{m}]$ filter) seawater, with a salinity of approximately 33 psu. Sample cups for September 2009 to the present (November 2013) contain a density-gradient solution with a salinity of approximately 44 psu. Formalin (3.7 percent) and sodium borate are added to the density-gradient solution to poison and preserve the samples. The trap was recovered and redeployed every 3 months during 2008, and approximately every 6 months thereafter. A gap in sampling occurred from late May to late September 2009 and the beginning of February to late March 2012 due to scheduling problems. Nine samples from the weeks of March 17, April 7, May 5, October 22, November 19, and December 10, 2009, and January 7, February 14, and February 24, 2010, were not recovered due to loss of the cups during deployment/recovery. During each visit to the trap site, water-column profile measurements were collected using a Sea-Bird Electronics SBE9plus conductivity-temperature-depth (CTD) instrument (figs. 2 and 3).

Sediment-trap samples were wet split into four aliquots using a precision rotary splitter at the University of South Carolina, stored in buffered deionized water, and then refrigerated. A quarter split was wet sieved over a $150-\mu \mathrm{m}$ sieve and subsequently wet picked for all foraminifers. In samples with fewer than 300 foraminifers in the first quarter split, an additional one-quarter split was processed. The counts were then summed. All planktic foraminifers were identified to species. The species counts are reported as flux in tests per square meter per day $\left(\mathrm{m}^{-2} \mathrm{day}^{-1}\right)$. Flux was calculated by multiplying the individual species counts by number of splits, then dividing by sampling length, which was typically 7 or 14 days. Percent abundance (percent of each species within each cup) is reported weekly and for each season. Seasonal flux is the total flux for each individual species. Seasons are defined as winter (January, February, and March), spring (April, May, and June), summer (July, August, and September), and fall (October, November, and December). Relative seasonal abundances were calculated by dividing the individual species' total seasonal flux by the total seasonal flux for all planktic foraminifers.

\section{Results from 2012}

From the sediment-trap material, 10 species, or varieties, of planktic foraminifers constituted $\sim 92$ percent of the 2012 assemblage: Globigerinoides ruber (d'Orbigny) (pink and white varieties), Gs. saccu- 
lifer (Brady), Globigerina calida Parker, Globigerinella aequilateralis (Brady), Globorotalia menardii group [the Gt. menardii group includes Gt. menardii (Parker, Jones, and Brady), Gt. tumida (Brady), and Gt. ungulata Bermudez], Orbulina universa d'Orbigny, Gt. truncatulinoides (d'Orbigny), Pulleniatina spp., and Neogloboquadrina dutertrei (d'Orbigny) (table 1; figs. 4 and 5).

The mean daily flux of planktic foraminifers recovered from the trap in 2012 was 158 tests $^{-2}$ day $^{-1}$ (table 1; fig. 4). The winter (January, February, and March) flux contributed about 12 percent of the annual flux and ranged from 8 to 229 tests $\mathrm{m}^{-2}$ day $^{-1}$, with a mean flux of 113 tests $\mathrm{m}^{-2}$ day $^{-1}$. Spring (April, May, and June) flux contributed about 42 percent of the annual flux and ranged from 57 to 438 tests $\mathrm{m}^{-2}$ day $^{-1}$, with a mean flux of 202 tests $\mathrm{m}^{-2}$ day $^{-1}$. Summer (July, August, and September) flux contributed about 26 percent of the annual flux and ranged from 7 to 463 tests $\mathrm{m}^{-2}$ day $^{-1}$, with a mean flux of 184 tests $\mathrm{m}^{-2} \mathrm{day}^{-1}$. The fall (October, November, and December) flux contributed about 20 percent of the annual flux and ranged from 20 to 293 tests $\mathrm{m}^{-2}$ day $^{-1}$, with a mean flux of 113 tests $\mathrm{m}^{-2}$ day $^{-1}$.

Globortotalia truncatulinoides was the most abundant species in the winter season, comprising $\sim 27$ percent of the assemblage during January and February (fig. 5). The spinose species Globigerinoides ruber (pink) (17 percent), Globigerinoides ruber (white) (12 percent), Globigerinoides sacculifer (13 percent), Globigerina calida (14 percent), and Globigerinella aequilateralis (13 percent) accounted for the bulk of the spring percentage ( $\sim 69$ percent). The summer season was dominated by the Globigerinoides genus [Gs. ruber (pink), Gs. ruber (white), and Gs. sacculifer], which made up $\sim 69$ percent of the total assemblage. Gs. ruber (pink; 12 percent), Gs. ruber (white; 17 percent), Gs. sacculifer (18 percent), Gl. aequilateralis (14 percent), N. dutertrei (8 percent), Pulleniatina spp. (11 percent), and the Gt. menardii group ( 8 percent) accounted for $\sim 88$ percent of the fall assemblage.

\section{Conclusions}

Sediment-trap data collected from January 2008 to December 2012 indicate that 10 species/groups of planktic foraminifers composed $\sim 92$ percent of the total flux. Globorotalia truncatulinoides flux data indicate that the species almost exclusively is present in January and February. The addition of 2012 data to the 2008-2011 flux and percentage data provides for a better understanding of the inter- and intra-annual variability. A longer time series is needed to distinguish the natural range of all foraminiferal species.

\section{Acknowledgments}

We thank Don Hickey, Eric Tappa, Katie Richwine, Joe Malbrough, and the crew of the R/V Pelican for assistance in deploying and redeploying the sediment-trap mooring. 


\section{References}

Antonov, J.I., Seidov, D., Boyer, T.P., Locarnini, R.A., Mishonov, A.V., Garcia, H.E., Baranova, O.K., Zweng, M.M., and Johnson, D.R., 2010, World Ocean Atlas 2009, Volume 2: Salinity, in Levitus, S., ed., NOAA atlas NESDIS 69: Washington, D.C., U.S. Government Printing Office, 184 p.

Kennett, J.P., Elmstrom, K., and Penrose, N.L., 1985, The last deglaciation in Orca Basin, Gulf of Mexico: High-resolution planktonic foraminifera changes: Palaeogeography, Paleoclimatology, Paleoecology, v. 50, p. 189-216.

Locarnini, R.A., Mishonov, A.V., Antonov, J.I., Boyer, T.P., Garcia, H.E., Baranova, O.K., Zweng, M.M., and Johnson, D.R., 2010, World ocean atlas 2009, Volume 1: Temperature, in Levitus, S., ed., NOAA atlas NESDIS 68: Washington, D.C., U.S. Government Printing Office, 184 p.

LoDico, J.M., Flower, B.P., and Quinn, T.M., 2006, Subcentennial-scale climatic and hydrologic variability in the Gulf of Mexico during the early Holocene: Paleoceanography, v. 21, doi:10.1029/2005PA001243.

Poore, R.Z., Tedesco, K.A., and Spear, J.W., 2013, Seasonal flux and assemblage composition of planktic foraminifers from a sediment-trap study in the northern Gulf of Mexico, in Brock, J.C., Barras, J.A., and Williams, S.J., eds., Understanding and predicting change in the coastal ecosystems of the northern Gulf of Mexico: Journal of Coastal Research, Special Issue No. 63, p. 6-19: Coconut Creek (Florida), ISSN 0749-0208.

Poore, R.Z., Verardo, S., Caplan, J., Pavich, K., and Quinn, T., 2011, Planktic foraminiferal relative abundance trends in the Gulf of Mexico Holocene sediments-Records of climate variability, in Holmes, C., ed., Gulf of Mexico - Its origins, waters, biota, and human impact: University Texas Press.

Tedesco, K.A., Spear, J.W., Tappa, Eric, and Poore, R.Z., 2009, Seasonal flux and assemblage composition of planktic foraminifera from the northern Gulf of Mexico: U.S. Geological Survey Open-File Report 2009-1293, 19 p.

Wang, Chunzai, and Enfield, D.B., 2001, The tropical Western Hemisphere Warm Pool: Geophysical Research Letters, v. 28, p. 1635-1638.

Wang, Chunzai, Enfield, D.B., Lee, Sang-ki, and Landsea, C.W., 2006, Influences of the Atlantic Warm Pool on Western Hemisphere summer rainfall and Atlantic hurricanes: Journal of Climate, v. 19, p. 3011-3028. 


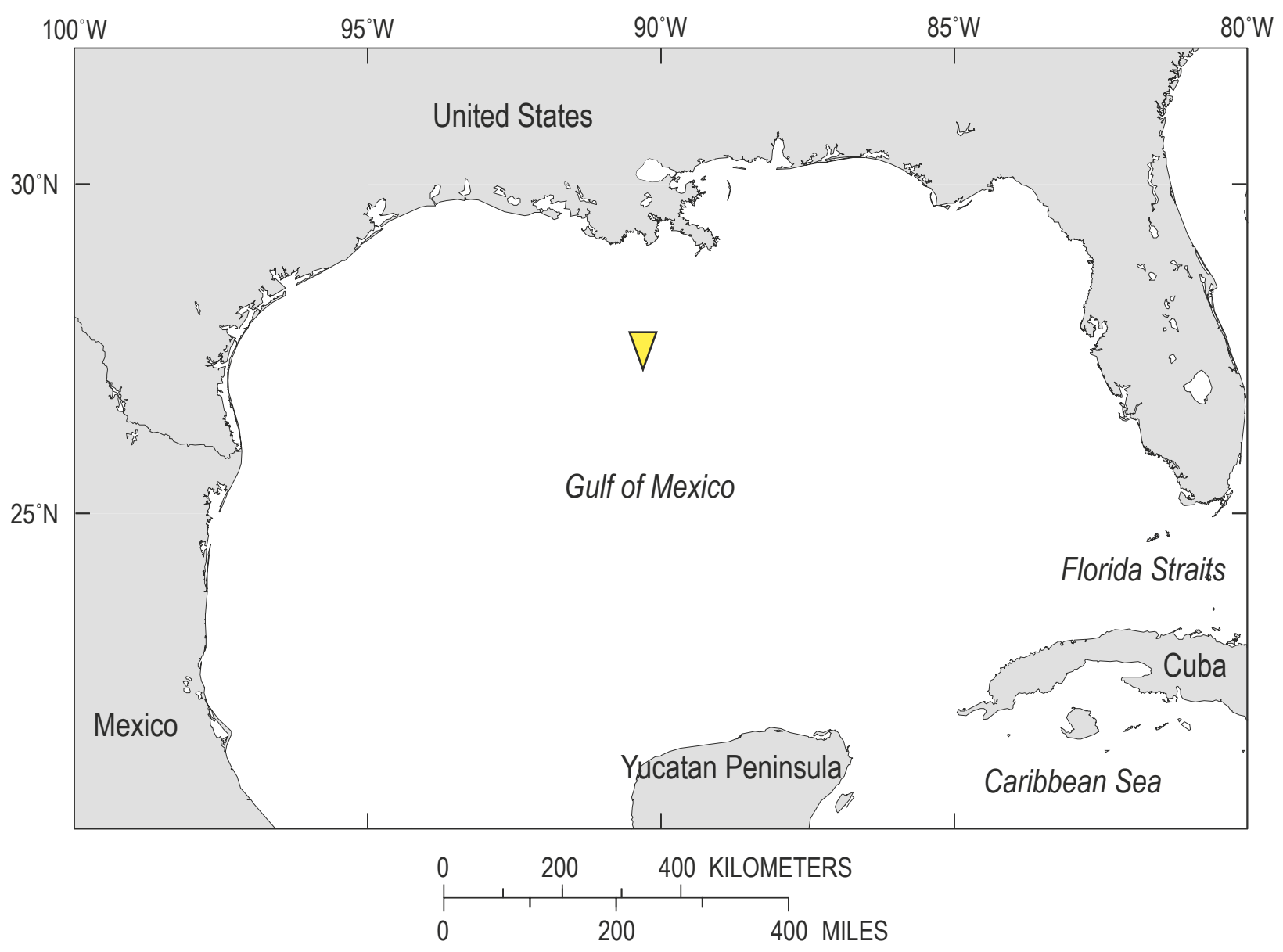

Figure 1. Location of the sediment-trap mooring (inverted triangle) in the northern Gulf of Mexico at approximately $25.7^{\circ} \mathrm{N}$ latitude and $90.3^{\circ} \mathrm{W}$ longitude. 

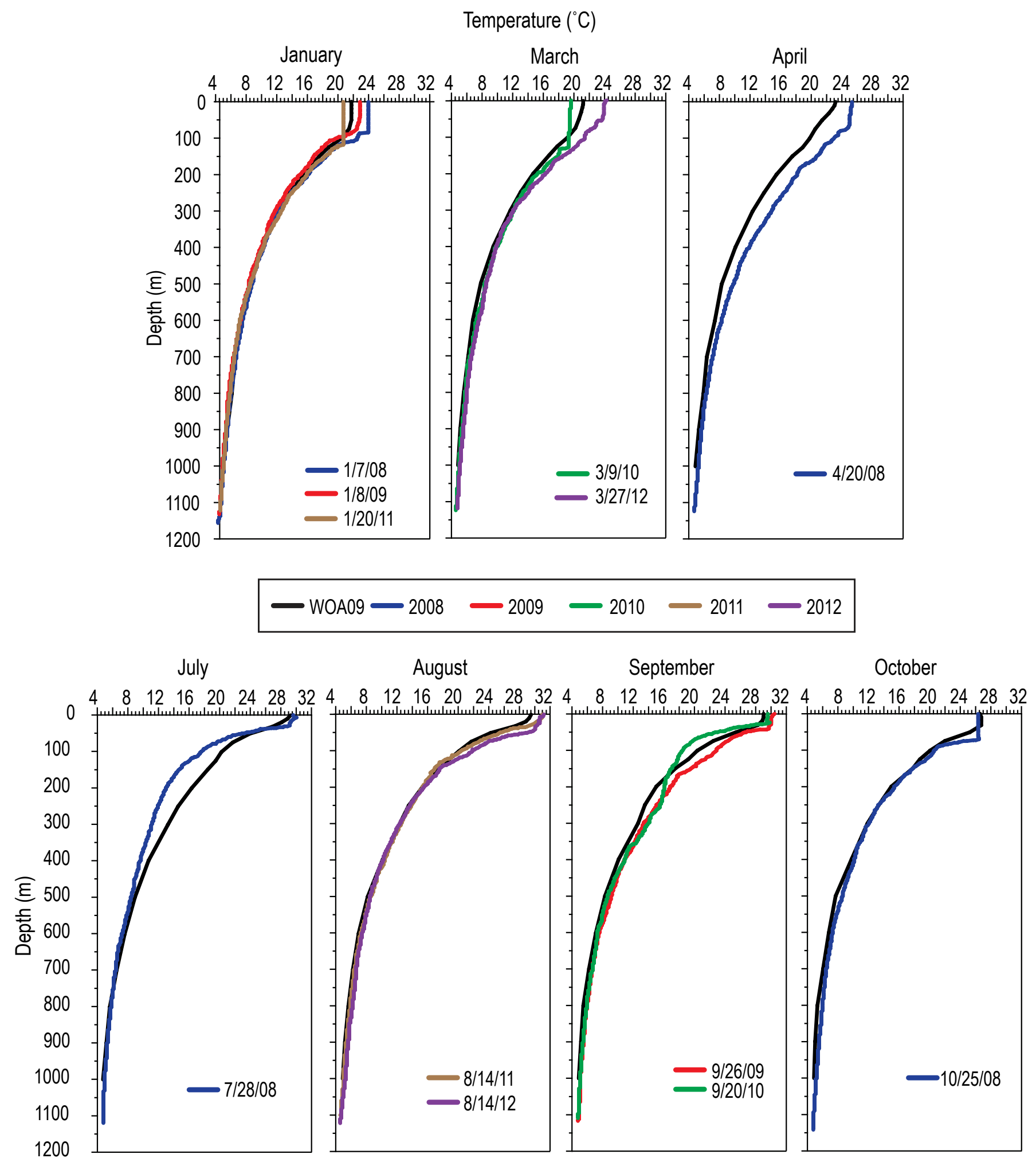

Figure 2. Temperature depth profiles of World Ocean Atlas 2009 climatology (monthly average) (WOA09) and conductivity-temperature-depth (CTD) casts for the sediment trap during 2008-2012. 
Salinity (psu)
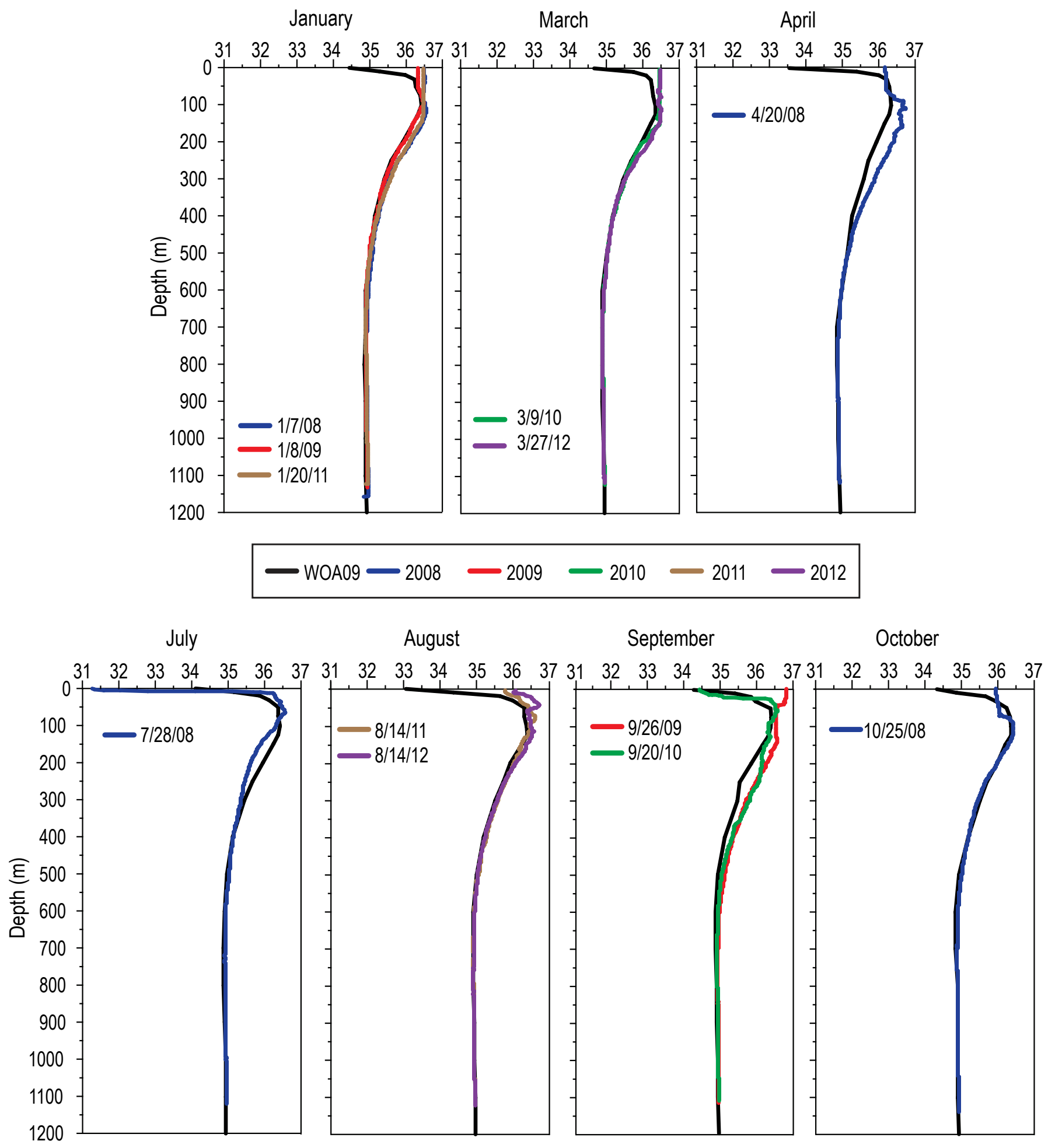

Figure 3. Salinity depth profiles of World Ocean Atlas 2009 climatology (monthly average) (WOA09) and conductivity-temperature-depth (CTD) casts for the sediment trap during 2008-2012. 


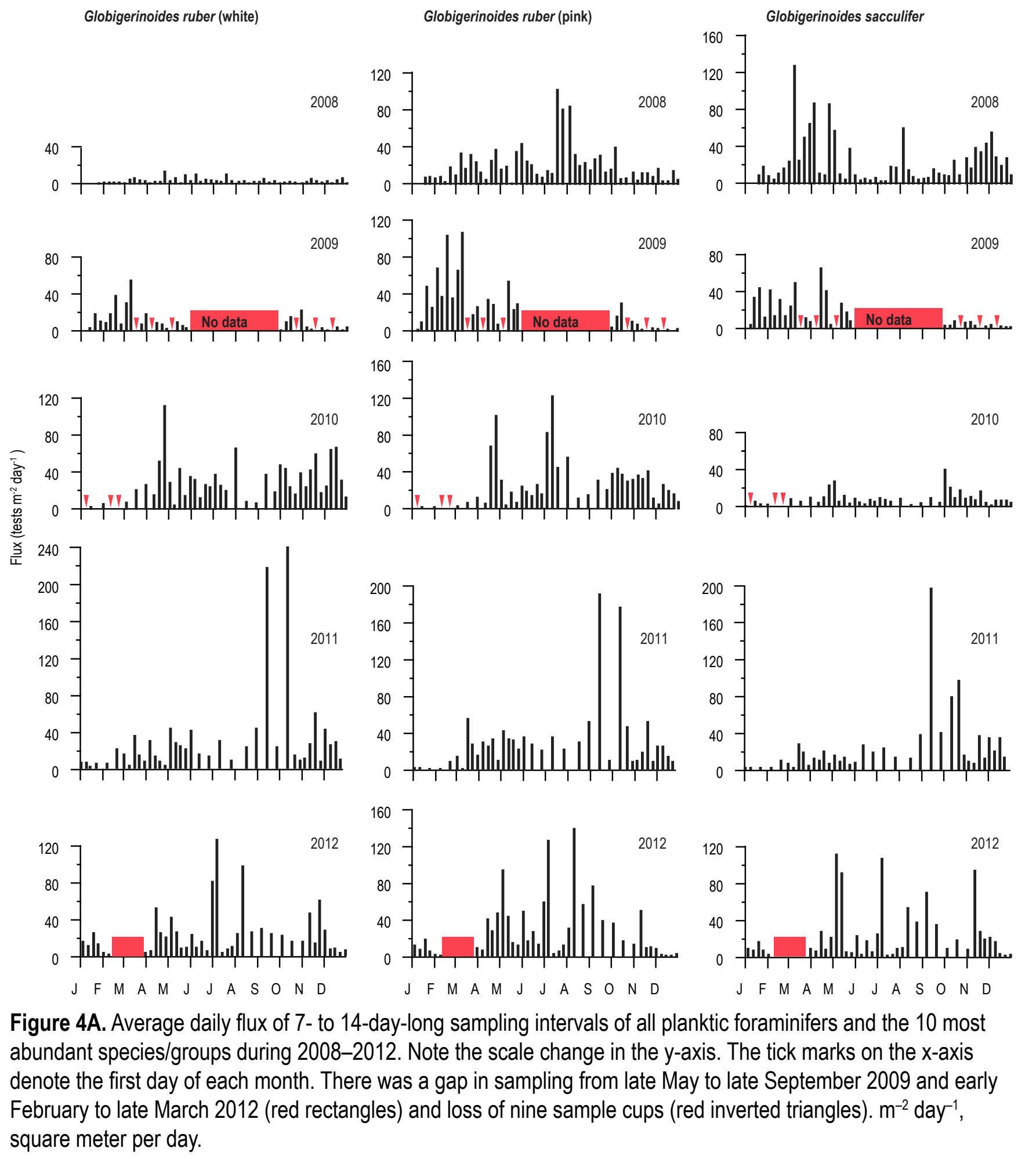


Globorotalia truncatulinoides
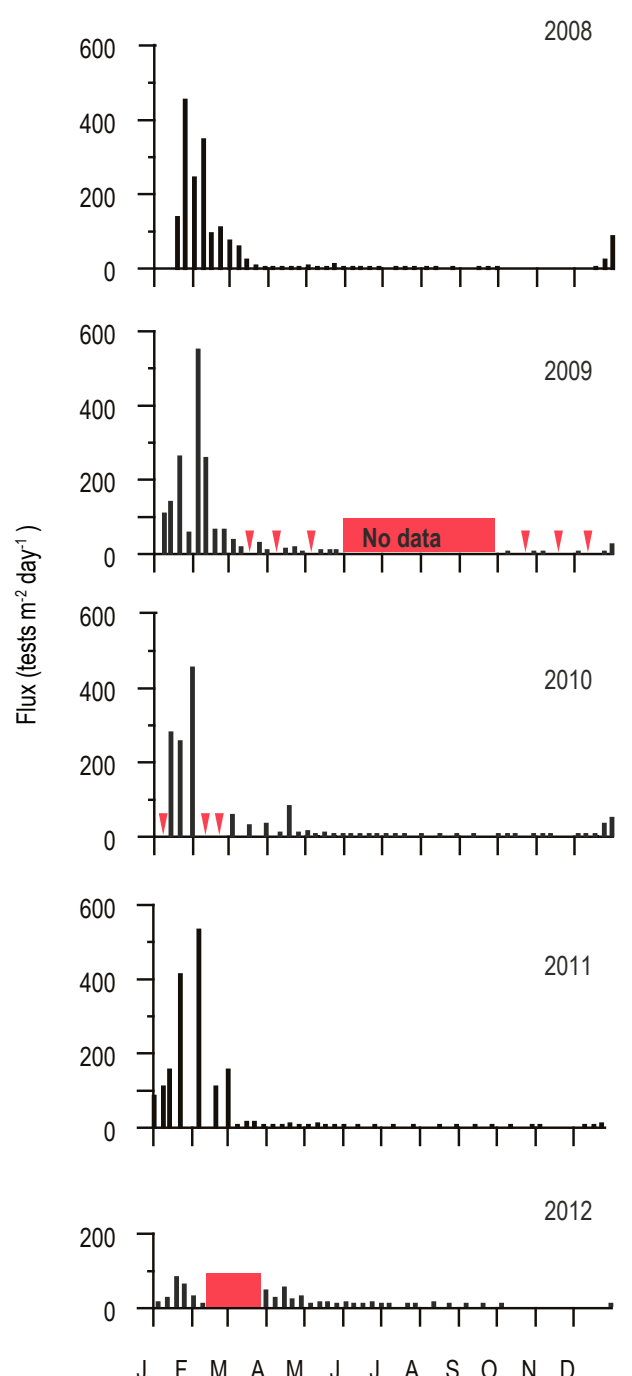

Neogloboquadrina dutertrei
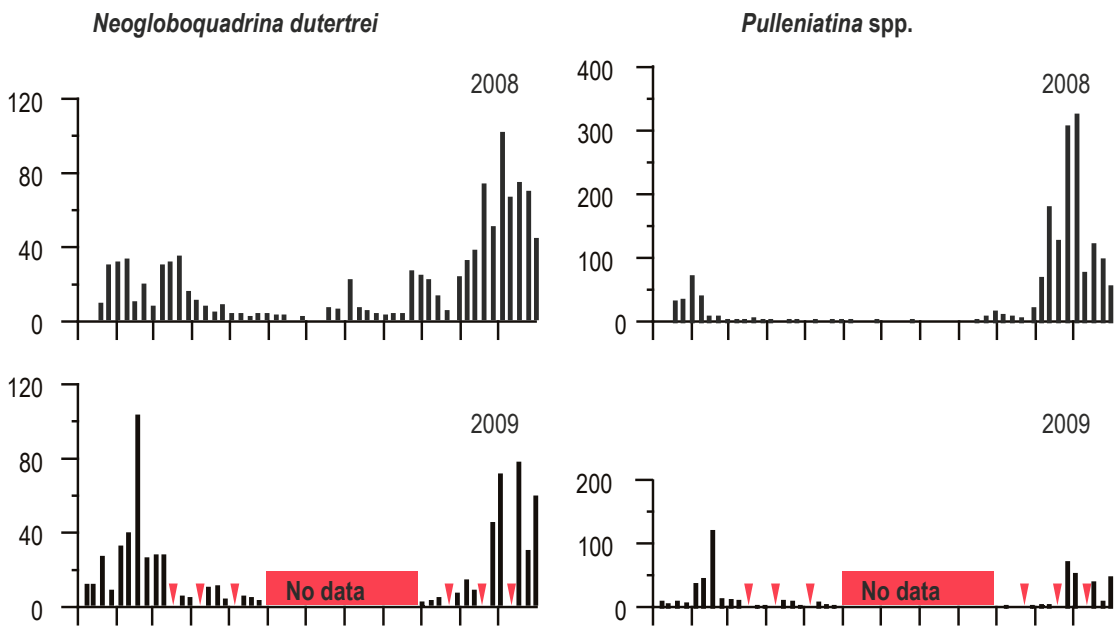

2009

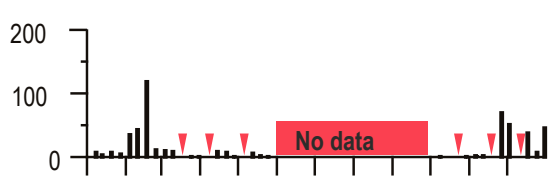

2010
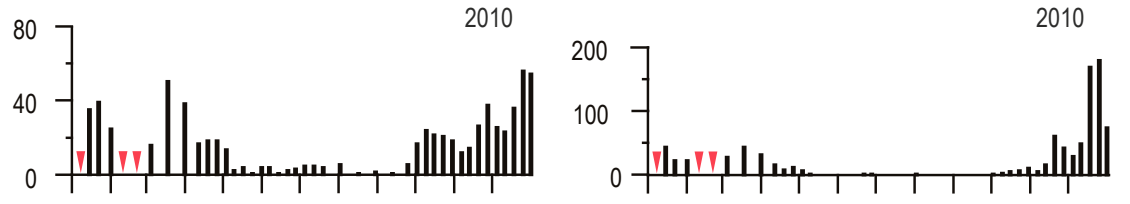

2011
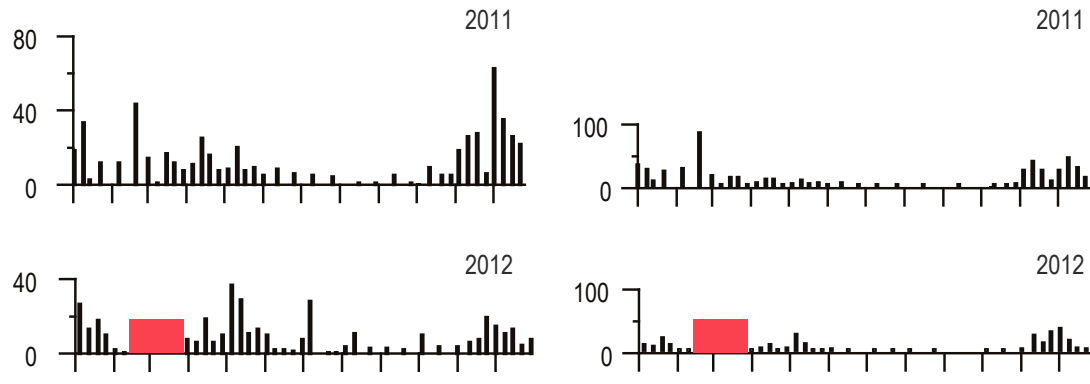

$\begin{array}{llllllllllll} & F & M & A & M & J & J & A & S & O & N & D\end{array}$

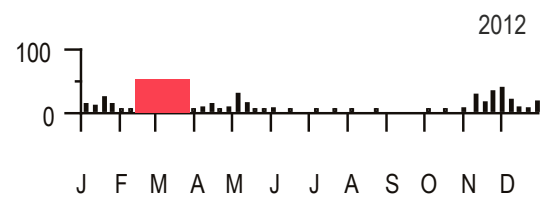

Figure 4B. Average daily flux of 7- to 14-day-long sampling intervals of all planktic foraminifers and the 10 most abundant species/groups during 2008-2012. Note the scale change in the y-axis. The tick marks on the x-axis denote the first day of each month. There was a gap in sampling from late May to late September 2009 and early February to late March 2012 (red rectangles) and loss of nine sample cups (red inverted triangles). $\mathrm{m}^{-2}$ day $^{-1}$, square meter per day. 

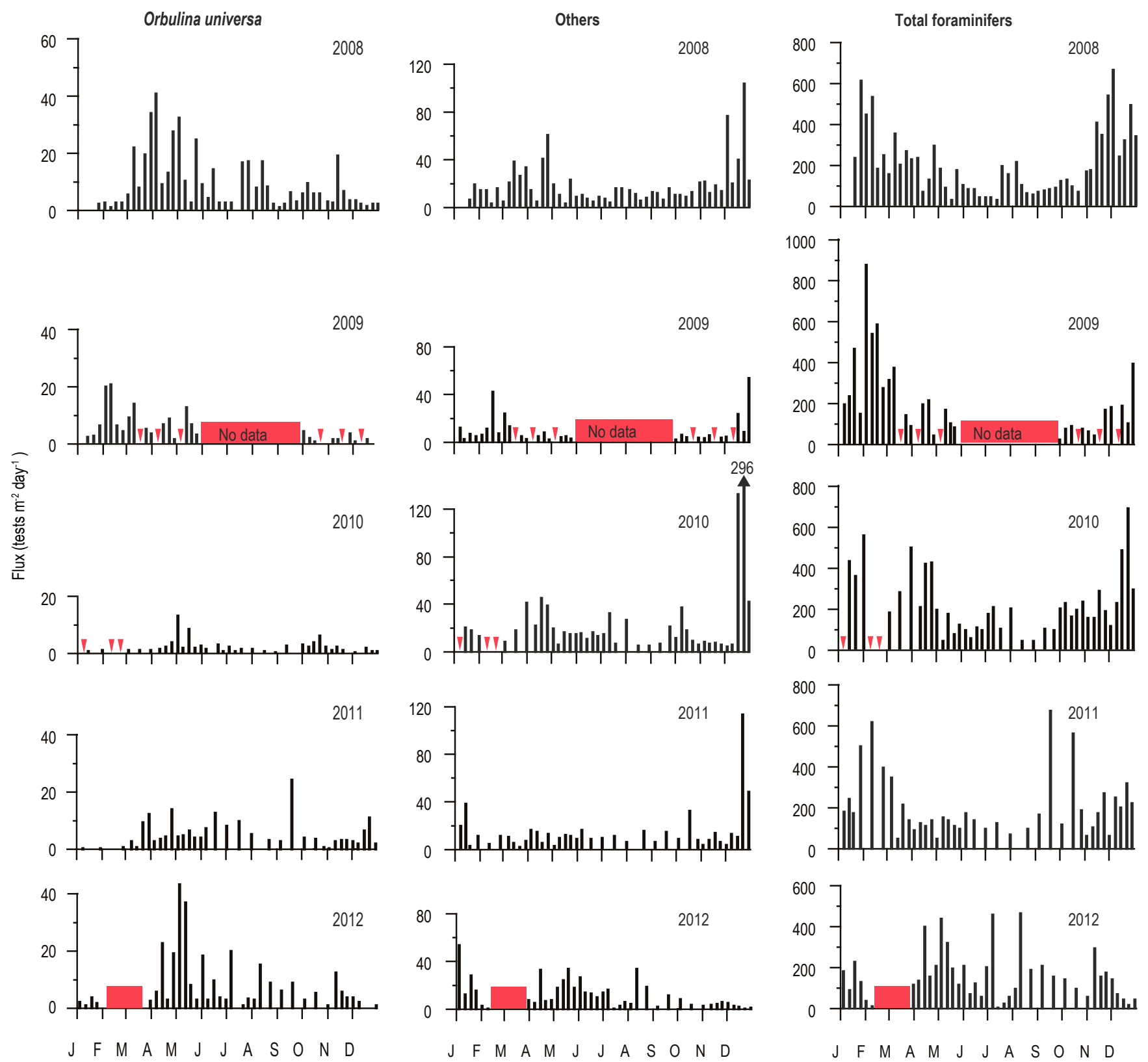

Figure 4C. Average daily flux of 7- to 14-day-long sampling intervals of all planktic foraminifers and the 10 most abundant species/groups during 2008-2012. Note the scale change in the y-axis. The tick marks on the x-axis denote the first day of each month. There was a gap in sampling from late May to late September 2009 and early February to late March 2012 (red rectangles) and loss of nine sample cups (red inverted triangles). $\mathrm{m}^{-2}$ day $^{-1}$, square meter per day. 


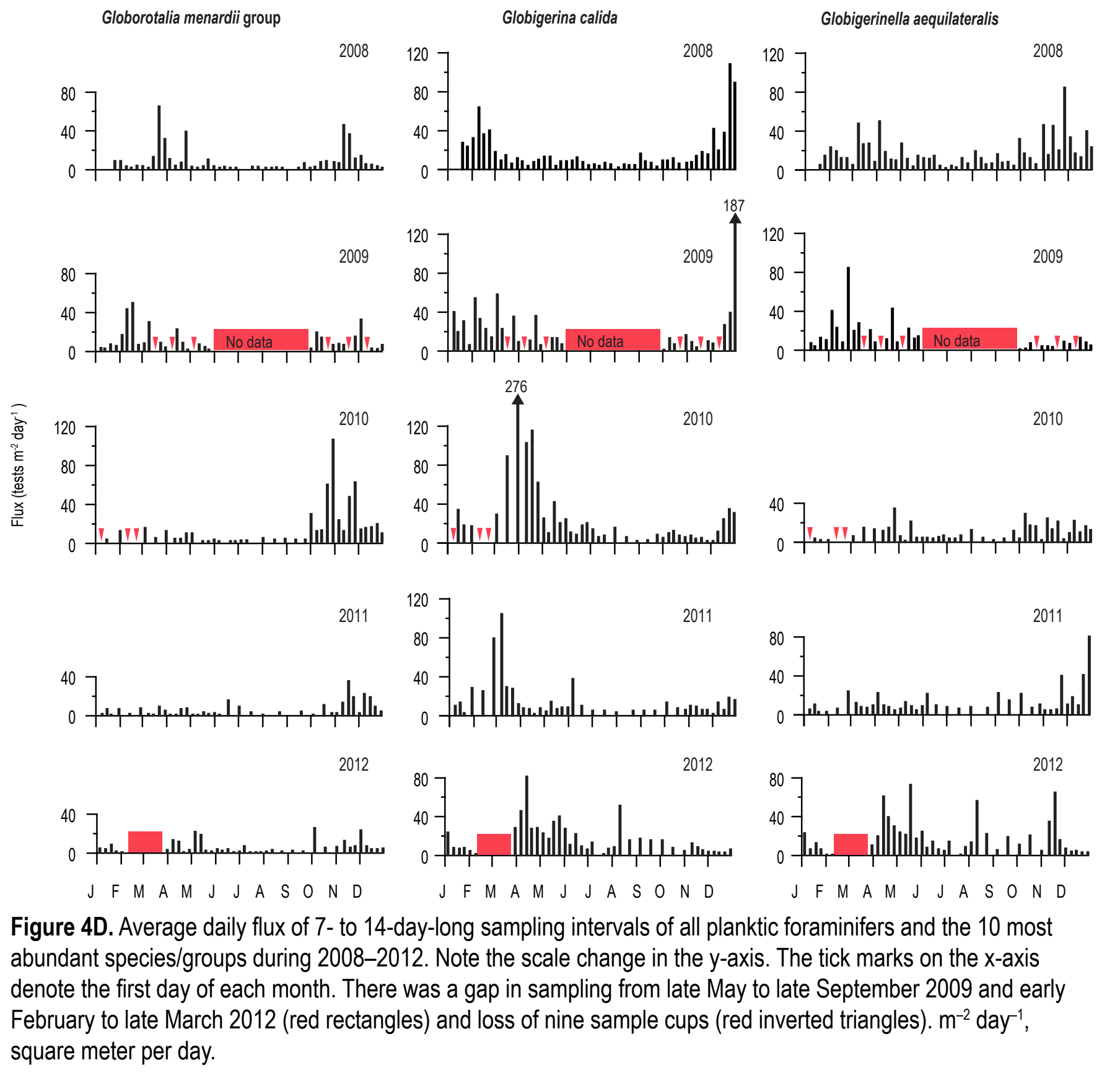


Globigerinoides ruber (white)
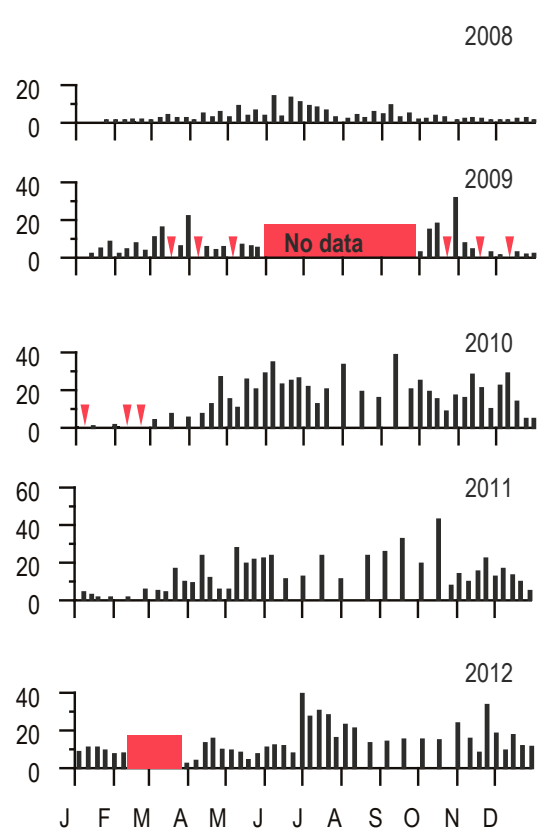

Globigerinoides ruber (pink)

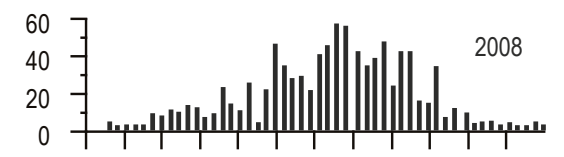

20 - ב

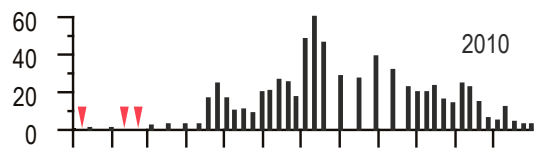

2011
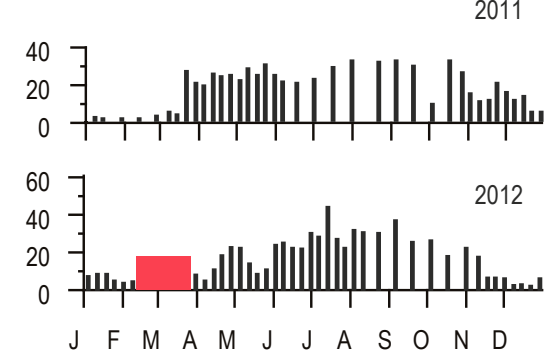

Globigerinoides sacculifer

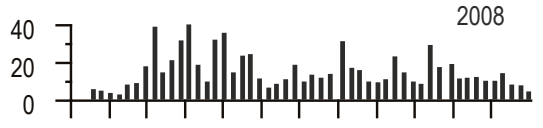

2009
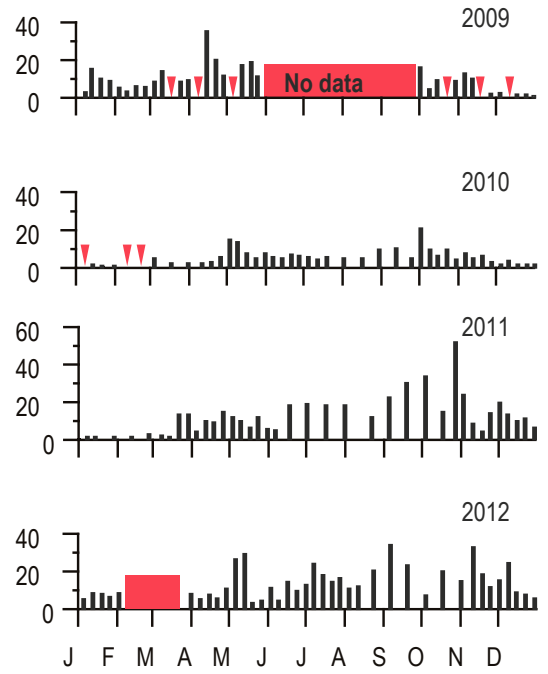

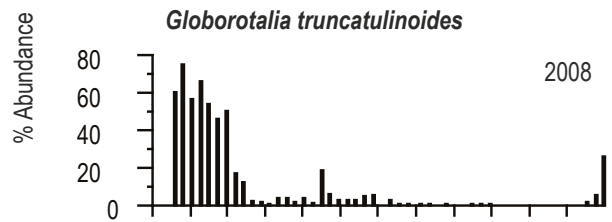

Neogloboquadrina dutertrei

Pulleniatina spp.
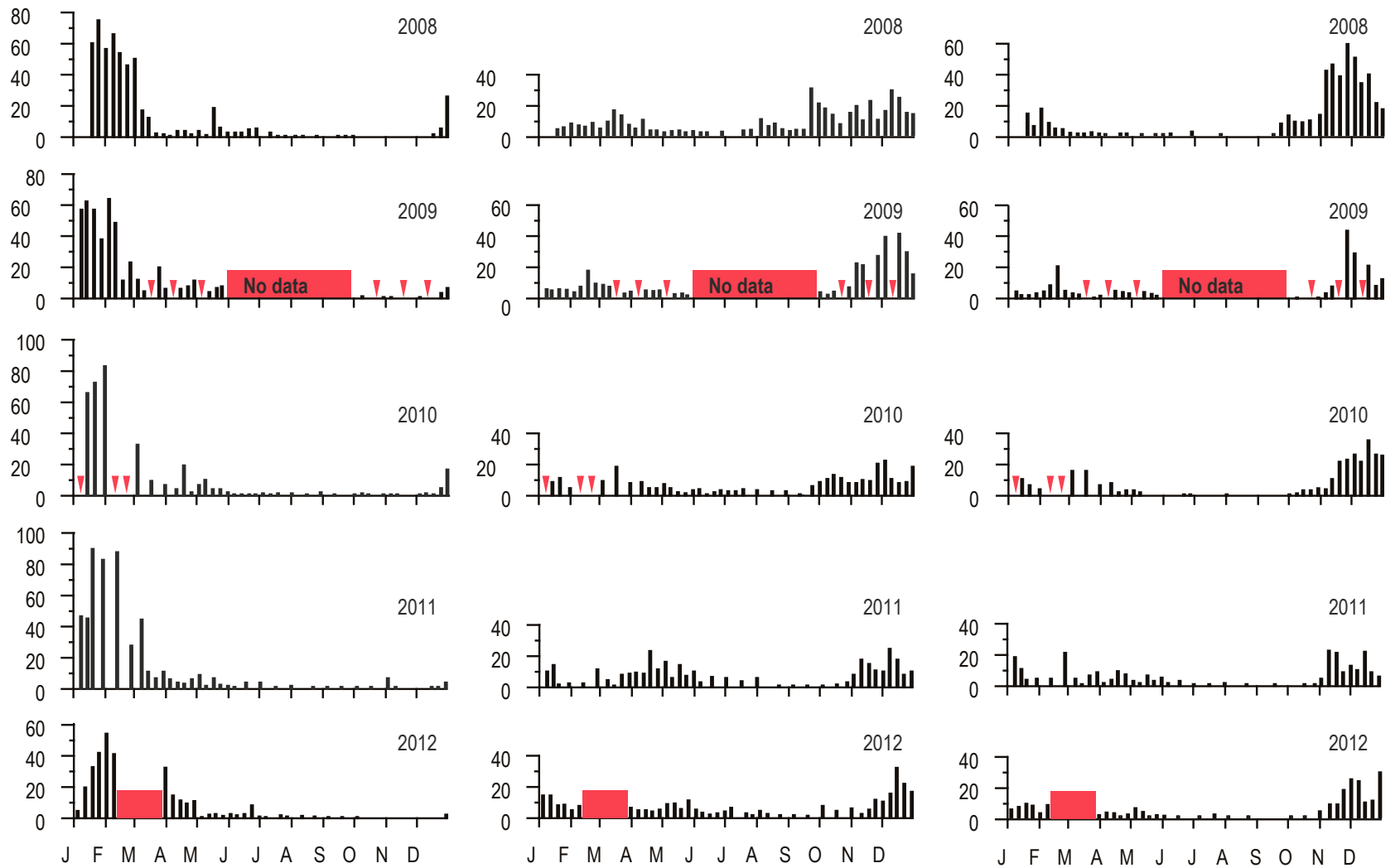

Figure 5A. Weekly percent abundance of the 10 most common species/groups of planktic foraminifers during 2008-2012. Note the scale change in the $y$-axis. The tick marks on the $x$-axis denote the first day of each month. There was a gap in sampling from late May to late September 2009 and early February to late March 2012 (red rectangles) and loss of nine sample cups (red inverted triangles). 


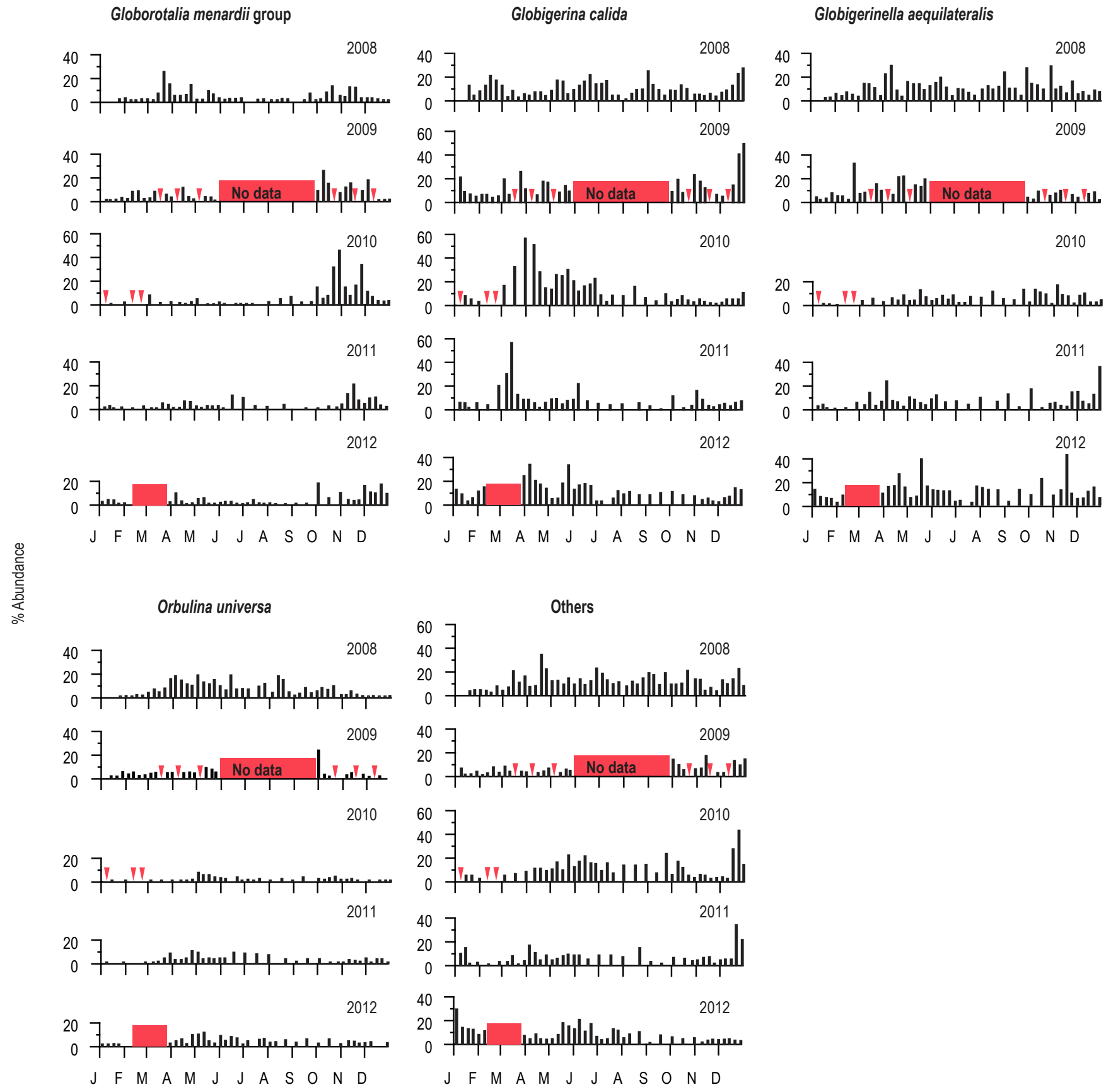

Figure 5B. Weekly percent abundance of the 10 most common species/groups of planktic foraminifers during 2008-2012. Note the scale change in the $y$-axis. The tick marks on the $x$-axis denote the first day of each month. There was a gap in sampling from late May to late September 2009 and early February to late March 2012 (red rectangles) and loss of nine sample cups (red inverted triangles). 